\title{
Influence of the binder used in pressing ash for laser sampling on the quality of analytical signals of the elements detected
}

\author{
(C) Roman P. Kolmykov, ${ }^{+}$Anna V. Petrushina, and Sergey A. Sozinov \\ ${ }^{1}$ Kemerovov State University. Krasnaya St., 6. Kemerovo, 650000. Russia. \\ ${ }^{2}$ Federal Research Center of Coal and Coal Chemistry of the SB RAS. \\ Sovietsky Ave., 18. Kemerovo, 650000. Russia. Phone: +7 (3842) 28-17-21. \\ E-mail:kolmykoff.roman@yandex.ru
}

*Supervising author; ${ }^{+}$Corresponding author

Keywords: ash, ICP OES, laser ablation.

\begin{abstract}
This work is devoted to determining the chemical composition of coal ashes. We used the optical emission spectrometry with inductively coupled plasma and laser sampling as a research method. The aim of the work is to determine the limits of detection (LoDs) and quantitative determination (LoQs) of elements in ashes using polyvinyl alcohol (PVA) and microcrystalline cellulose (MCC) as binders. In this work, analytical signals of Al, $\mathrm{Ba}, \mathrm{Be}, \mathrm{Ca}, \mathrm{Cr}, \mathrm{Cu}, \mathrm{Fe}, \mathrm{K}, \mathrm{La}, \mathrm{Li}, \mathrm{Mg}, \mathrm{Mn}, \mathrm{Na}, \mathrm{Ni}, \mathrm{P}, \mathrm{Pb}, \mathrm{S}, \mathrm{Sc}, \mathrm{Sr}, \mathrm{Ti}, \mathrm{Y}, \mathrm{V}, \mathrm{Zr}$, and $\mathrm{Zn}$ were analyzed in tablets obtained from the standard samples ZUK-1, ZUK-2, SG-1A, SG-3, SGD-2A, and SO-1, compacted using PVA and MCC, as well as from binding agents themselves. To obtain compact materials based on fly ash and geological materials, both binders are suitable if their chemical purity is enough for analysis. However, when using both MCC and PVA, some drawbacks were identified. The intensities of analytical lines of the elements were determined lower during the ablation of compact ashes with MCC than with PVA. The signal-background ratio is lower when using MCC as a binder material compared with compacts based on PVA. However, the highest grade PVA according to GOST 10779-78, used in the work, contains an admixture of sodium, about $0.06 \mathrm{w}$. \%, which interferes with quantitative measurements if the sodium content in the sample is comparable to this value, which can be extremely rare in the analysis of fly ashes.
\end{abstract}

\section{References}

[1] X. Li, S. Dai, W. Zhang, T. Li, X. Zheng, W. Chen. Determination of As and Se in coal and coal combustion products using closed vessel microwave digestion and collision/reaction cell technology (CCT) of inductively coupled plasma mass spectrometry (ICP-MS). International Journal of Coal Geology. 2014. Vol.124. P.1-4.

[2] A.K. Das, R. Chakraborty, de la M. Guardia, M.L. Cervera, D. Goswami. ICP-MS multielement determination in fly ash after microwave-assisted digestion of samples. Talanta. 2001. Vol.54. No.5. P.975-981.

[3] D.A. Spears. The use of laser ablation inductively coupled plasma-mass spectrometry (LA ICP-MS) for the analysis of fly ash. Fuel. 2004. Vol.83. No.13. P.1765-1770.

[4] K. Suzuki. Characterisation of airborne particulates and associated trace metals deposited on tree bark by ICP-OES, ICP-MS, SEM-EDX and laser ablation ICP-MS. Atmospheric Environment. 2006. Vol.40. No.14. P.2626-2634.

[5] F.G. Antes, F.A. Duarte, M.F. Mesko, M.A. Nunes, V.A. Pereira, E.I. Müller, E.M. Flores. Determination of toxic elements in coal by ICP-MS after digestion using microwave-induced combustion. Talanta. 2010. Vol.83. No.2. P.364-369.

[6] A. Smeda, W. Zyrnicki. Application of sequential extraction and the ICP-AES method for study of the partitioning of metals in fly ashes. Microchemical Journal. 2002. Vol.72. No.1. P.9-16.

[7] A. Iwashita, T. Nakajima, H. Takanashi, A. Ohki, Y. Fujita, T. Yamashita. Determination of trace elements in coal and coal fly ash by joint-use of ICP-AES and atomic absorption spectrometry. Talanta. 2007. Vol.71. No.1. P.251-257.

[8] A. Iwashita, T. Nakajima, H. Takanashi, A. Ohki, Y. Fujita, T. Yamashita. Effect of pretreatment conditions on the determination of major and trace elements in coal fly ash using ICP-AES. Fuel. 2006. Vol.85. No.2. P.257-263. 
INFLUENCE OF THE BINDER USED IN PRESSING ASH FOR LASER SAMPLING ON THE QUALITY...

[9] F. Low, L. Zhang. Microwave digestion for the quantification of inorganic elements in coal and coal ash using ICP-OES. Talanta. 2012. Vol.101. P.346-352.

[10] J. Wang, T. Nakazato, K. Sakanishi, O. Yamada, H. Tao, I. Saito. Microwave digestion with $\mathrm{HNO} 3 / \mathrm{H} 2 \mathrm{O} 2$ mixture at high temperatures for determination of trace elements in coal by ICP-OES and ICP-MS. Analytica chimica acta. 2004. Vol.514. No.1. P.115-124.

[11] L. Ebdon, E.H. Evans. An introduction to analytical atomic spectrometry. John Wiley \& Sons. 1998.

[12] I.J. Alinnor. Adsorption of heavy metal ions from aqueous solution by fly ash. Fuel. 2007. Vol.86. P.853-857.

[13] G. Schlemmer, B. Welz. Determination of heavy metals in environmental reference materials using solid sampling graphite furnace AAS. Fresenius' Journal of Analytical Chemistry. 1987. Vol.328. No.4. P.405-409.

[14] S. Sushil, V.S. Batra. Analysis of fly ash heavy metal content and disposal in three thermal power plants in India. Fuel. 2006. Vol.85. No.17. P.2676-2679.

[15] B.F. Arbogast. Analytical Methods Manual for the Mineral Resource Surveys Program, US Geological Survey. US Department of the Interior, US Geological Survey. 1996.

[16] R. Singh, D.P. Singh, N. Kumar, S.K. Bhargava, S.C. Barman. Accumulation and translocation of heavy metals in soil and plants from fly ash contaminated area. Journal of Environmental Biology. 2010. Vol.31. P.421-430.

[17] L. Vincze, A. Somogyi, J. Osan, B. Vekemans, S. Toeroek, K. Janssens, F. Adams. Quantitative trace element analysis of individual fly ash particles by means of X-ray microfluorescence. Analytical chemistry. 2002. Vol.74. No.5. P.1128-1135.

[18] O. Dogan, M. Kobya. Elemental analysis of trace elements in fly ash sample of Yatağan thermal power plants using EDXRF. Journal of Quantitative Spectroscopy and Radiative Transfer. 2006. Vol.101. No.1. P.146-150.

[19] O. Dogan, Ö. Symsek, Y. Nuhoglu, M. Kopya, \& M. Ertugrul. X-ray fluorescence spectrometry analysis of trace elements in fly ash samples of Kemerköy thermal power plants. Journal of trace and microprobe techniques. 2001. Vol.19. No.2. P.289-295.

[20] B.G. Kutchko, A.G. Kim. Fly ash characterization by SEM-EDS. Fuel. 2006. Vol.85. No.17. P.2537-2544.

[21] http://www.igc.irk.ru/ru/component/flexicontent/186-gruppa-25-4/3412-standartnye-obraztsysostava?Itemid=746 (08.07.2019). 